Article

\title{
Wine Lactic Acid Bacteria with Antimicrobial Activity as Potential Biocontrol Agents against Fusarium oxysporum f. sp. lycopersici
}

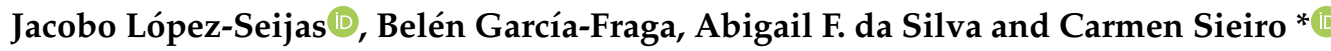 \\ Department of Functional Biology and Health Sciences. University of Vigo Lagoas-Marcosende, \\ 36310 Vigo, Spain; lopezseijasjacobo@gmail.com (J.L.-S.); belengarciafraga@gmail.com (B.G.-F.); \\ abi_fdez@hotmail.com (A.F.d.S.) \\ * Correspondence: mcsieiro@uvigo.es
}

Received: 18 November 2019; Accepted: 20 December 2019; Published: 24 December 2019

check for updates

\begin{abstract}
Lactic acid bacteria isolated from wine fermentations, particularly from the malolactic fermentation, and belonging to Lactobacillus plantarum, Lactobacillus hilgardii, Lactobacillus paracasei and Lactococcus lactis species were tested for their effectiveness in inhibiting the development of different microorganisms. The different strains showed, to varying degrees, an antagonistic effect against bacteria of the genera Bacillus and Staphylococcus. The specificity of the species L. hilgardii that inhibits only strains of the genus Bacillus is remarkable, on the other hand, L. plantarum was more effective against the strains of the genus Staphylococcus. The greatest effectiveness, considering both the degree of inhibition and the number of inhibited species, was presented by strains of L. lactis and L. paracasei. Seven strains belonging to the species that showed a more broad-spectrum activity, L. paracasei and L. plantarum, were also tested for their ability to inhibit the growth of fungi. All of them showed, in different degree (55-76\%), activity against Fusarium oxysporum. Finally, the ability of the L. paracasei LPAUV12 and L. plantarum LPLUV10 strains was evaluated to protect Lycopersicon esculentum plants against the fungus F. oxysporum and promote its growth. Strain LPLUV10, showed capacity to significantly inhibit the harmful effect of F. oxysporum in tomato plants as well as to significantly stimulate their growth.
\end{abstract}

Keywords: lactic acid bacteria; antimicrobial activity; biocontrol agents; plant growth promoters

\section{Introduction}

Pests produced by phytopathogenic fungi that affect agricultural crops cause losses ranging from $5-10 \%$ of world agricultural production [1]. Twenty-five percent of the world's agricultural crops are affected by these microorganisms [2], responsible for the consequent economic losses. On the other hand, the development of fungi, yeasts, and bacteria in foods for consumption, is the main cause of food spoilage [3,4] that causes losses estimated at 25\% [3].

The proliferation of undesirable microorganisms in food causes, in the first place, undesirable alterations in their sensory characteristics and/or texture [3,5]. But in addition, the uncontrolled development of some of these microorganisms can represent a serious risk to human health due to its pathogenic nature [6] or its ability to synthesize toxic substances such as aflatoxins, ochratoxins, etc., which can cause carcinogenesis, hepatotoxicity, immunotoxicity or neurotoxicity [7].

Traditionally, pesticides and preservative agents of chemical synthesis are used both for the control of phytopathogens that attack agricultural crops and to prevent the development of food spoilage microorganisms. These compounds have contributed to increase the productivity and quality of food; however, they have been shown to be highly polluting and very harmful to human health. Besides, 
we must take into account the constant appearance of resistant pathogenic strains which reduces the number and type of available pesticides [8].

Due to the problems inherent in the use of chemical pesticides, there is a tendency to reduce and restrict the use of pesticides, which is materialized in the progressive prohibition of the most toxic products [9]. To all this we must add the growing awareness of the population in relation to this problem and, consequently, the growing rejection of consumers towards foods treated with these products $[4,10]$.

In line with the approach described above, there is a growing need and demand, both from industry and consumers, for the new technical systems [11] including the new pesticides and preservative agents that are non-toxic and friendly with the environment [12-15]. Biological control is the most widely accepted alternative [8] and consists of the use of microorganisms and abiotic products (like essential oils or salts) with antimicrobial properties such as biopesticides and bio-preservatives. There are different strains of bacteria, fungi and yeasts species, mostly belonging to the genera Trichoderma, Bacillus, Pseudomonas and Streptomyces, which have demonstrated their effect as biocontrol agents and which are marketed for this purpose [16-18]. New purposes, like the ability of Rhodococcus erythropolis to prevent plant diseases by disrupting quorum sensing-based communication of gram-negative soft-rot bacteria, represent promising options for the future [19]. In addition, often, these microorganisms also act as phyto stimulants, which also reduces the use of chemical fertilizers with the consequent advantage from the economic and environmental point of view [20]. Despite the alternative represented by biopesticides for the control of pests, their use continues to be a minority when compared to the use of synthetic pesticides, mainly due to the perception of less effectiveness and their higher cost [16]. In this sense, the complete substitution of conventional pesticides by biopesticides and bio-preservatives, particularly of microbial origin, will depend on the availability of safe, robust and effective strains capable of carrying out their activity, under different conditions, against different food spoilage and pathogenic microorganisms.

Lactic acid bacteria (LAB) have also been studied as possible biocontrol agents (BCAs), demonstrating their effectiveness against bacteria, yeasts, and above all, filamentous fungi [7]. These findings have been regarded as of great interest because, fundamentally, they are microorganisms considered GRAS (Generally Recognized as Safe) by the Food and Drug Administration (FDA, USA) and with the "Qualified Presumption of Safety" (QPS) status by the European Food Safety Agency (EFSA). Like in other microorganisms [21], the antagonistic and bio protective capacity of LABs is attributed to competition for nutrients (colonization) and antibiosis due to their ability to synthesize different antimicrobial compounds, including organic acids, bacteriocins, hydrogen peroxide and hydroxyl fatty acids [22].

Most of the biocontrol studies carried out with lactic acid bacteria have been performed with strains derived from dairy products. The so-called malolactic fermentation of wines is also driven by lactic acid bacteria, which come from the vine and its environment, and are developed and adapted to the hostile environment represented by wine, with a shortage of nutrients and high concentrations of ethanol and $\mathrm{SO}_{2}$.

The objective of this study was to evaluate the antimicrobial activity of wine lactic acid bacteria and its potential as BCAs and Plant Growth Promoters (PGPs) that was not studied so far.

\section{Materials and Methods}

\subsection{Strains and Culture Media}

Twenty-two strains of wine lactic acid bacteria belonging to Lactobacillus plantarum, L. paracasei, L. hilgardii and Lactococcus lactis species (Table 1), previously isolated from wine fermentations and identified by our laboratory using different molecular techniques (rDNA $16 \mathrm{~S}$ and recA gene sequences, 16S-ARDRA and Intergenic Spacer Region (ISR) analysis), were used in this study. 
Table 1. Antimicrobial activity of lactic acid bacteria against target species.

\begin{tabular}{|c|c|c|c|c|c|c|c|c|}
\hline & \multirow[b]{2}{*}{ LAB Strain } & \multicolumn{7}{|c|}{ Target Species } \\
\hline & & Bacillus cereus & $\begin{array}{c}\text { Bacillus } \\
\text { thuringiensis }\end{array}$ & $\begin{array}{c}\text { Staphylococcus } \\
\text { epidermidis }\end{array}$ & $\begin{array}{c}\text { Staphylococcus } \\
\text { aureus }\end{array}$ & $\begin{array}{c}\text { Xanthomonas } \\
\text { campestris }\end{array}$ & $\begin{array}{c}\text { Saccharomyces } \\
\text { cerevisiae }\end{array}$ & $\begin{array}{l}\text { Candida } \\
\text { glabrata }\end{array}$ \\
\hline \multirow{10}{*}{ L. hilgardii } & LHIUV13 & - & $3.45 \pm 0.2 \mathrm{AB}$ & - & - & - & - & - \\
\hline & LHIUV14 & $1.96 \pm 0.3^{\mathrm{A}}$ & $5.83 \pm 0.1 \mathrm{ABE}$ & - & - & - & - & - \\
\hline & LHIUV15 & $2.01 \pm 0.1 \mathrm{~A}$ & $6.27 \pm 0.3 \mathrm{ABE}$ & - & - & - & - & - \\
\hline & LHIUV16 & $2.29 \pm 0.7^{\mathrm{A}}$ & $3.70 \pm 0.5 \mathrm{AB}$ & - & - & - & - & - \\
\hline & LHIUV17 & $0.55 \pm 0.3^{\mathrm{AC}}$ & $2.66 \pm 0.1 \mathrm{AB}$ & - & - & - & - & - \\
\hline & LHIUV18 & $0.70 \pm 0.2^{\mathrm{AC}}$ & $2.90 \pm 0.1 \mathrm{AB}$ & - & - & - & - & - \\
\hline & LHIUV20 & $0.69 \pm 0.3 \mathrm{AC}$ & $3.83 \pm 0.1 \mathrm{AB}$ & - & - & - & - & - \\
\hline & LHIUV21 & $4.97 \pm 0.1 \mathrm{BD}$ & - & - & - & - & - & - \\
\hline & LHIUV23 & $1.95 \pm 0.6^{\mathrm{A}}$ & $4.63 \pm 0.5^{\mathrm{ABD}}$ & - & - & - & - & - \\
\hline & LHIUV26 & $0.88 \pm 0.2 \mathrm{AC}$ & $5.65 \pm 0.1 \mathrm{ABE}$ & - & - & - & - & - \\
\hline \multirow{3}{*}{ L. plantarum } & LPLUV6 & - & nd & $6.81 \pm 0.5^{\mathrm{AD}}$ & $5.69 \pm 0.7^{\mathrm{A}}$ & - & - & - \\
\hline & LPLUV8 & - & - & - & - & - & - & - \\
\hline & LPLUV10 & - & $3.65 \pm 0.9^{\mathrm{AB}}$ & $6.47 \pm 0.2^{\mathrm{AD}}$ & $4.23 \pm 0.6 \mathrm{AC}$ & - & - & - \\
\hline \multirow{8}{*}{ L. paracasei } & LPAUV1 & $1.07 \pm 0.0^{\mathrm{A}}$ & $1.96 \pm 0.3 \mathrm{AB}$ & $3.85 \pm 0.4 \mathrm{AC}$ & $6.65 \pm 0.4^{\mathrm{A}}$ & - & - & - \\
\hline & LPAUV2 & $7.34 \pm 0.4^{\mathrm{B}}$ & nd & - & - & - & - & - \\
\hline & LPAUV3 & $0.96 \pm 0.0^{\mathrm{A}}$ & $1.53 \pm 0.2^{\mathrm{AC}}$ & $2.35 \pm 1.0^{\mathrm{AC}}$ & $4.54 \pm 0.4 \mathrm{AC}$ & - & - & - \\
\hline & LPAUV5 & - & $1.78 \pm 0.2 \mathrm{AC}$ & $2.83 \pm 0.7^{\mathrm{AC}}$ & $4.02 \pm 0.1 \mathrm{AC}$ & - & - & - \\
\hline & LPAUV7 & $0.88 \pm 0.2 \mathrm{AD}$ & $1.66 \pm 0.6 \mathrm{AC}$ & $4.39 \pm 0.2 \mathrm{AC}$ & $4.02 \pm 1.3 \mathrm{AC}$ & - & - & - \\
\hline & LPAUV11 & $0.87 \pm 0.3 \mathrm{AD}$ & $1.64 \pm 0.4 \mathrm{AC}$ & $5.80 \pm 0.9 \mathrm{AC}$ & $5.99 \pm 2.4 \mathrm{~A}$ & - & - & - \\
\hline & LPAUV12 & $1.30 \pm 1.2^{\mathrm{A}}$ & $1.75 \pm 0.1 \mathrm{AC}$ & $6.46 \pm 0.5 \mathrm{AD}$ & $10.25 \pm 0.5^{\mathrm{AB}}$ & - & - & - \\
\hline & LPAUV19 & $1.62 \pm 0.6^{\mathrm{A}}$ & $1.86 \pm 0.4^{\mathrm{AB}}$ & $5.42 \pm 0.8^{\mathrm{AC}}$ & $5.99 \pm 2.6^{\mathrm{A}}$ & - & - & - \\
\hline L. lactis & LLAUV27 & $8.72 \pm 3.4^{B}$ & nd & $12.29 \pm 0.4^{B}$ & $4.78 \pm 0.4 \mathrm{AC}$ & - & - & - \\
\hline
\end{tabular}

Values are mean \pm SD. Same capital letters within each column represent non-significant difference at $p \leq 0.05$. (-): no inhibition; (nd): not determined. LAB: lactic acid bacteria. 
Bacillus cereus CECT 193, Bacillus thuringiensis CECT 4497, Staphylococcus epidermidis CECT 231, Staphylococcus aureus subsp. aureus CECT 4439, Xanthomonas campestris CECT 97, Saccharomyces cerevisiae (our laboratory), Candida glabrata CECT 1448, Aspergillus niger CECT 2088, and Fusarium oxysporum $\mathrm{f}$. sp. lycopersici CECT 2715 were used as target bacteria, yeasts, and fungi, respectively. CECT: Spanish Type Culture Collection.

MRS (Man, Rogosa and Sharpe) medium (PanReac AppliChem, Spain) was used for LAB growth and preservation. Mueller-Hinton, Glucose-Sabouraud (PanReac AppliChem, Spain) and YEPD (yeast extract $20 \mathrm{~g} / \mathrm{L}$, peptone $10 \mathrm{~g} / \mathrm{L}$, glucose $20 \mathrm{~g} / \mathrm{L}$ ) media were used for growth and preservation of the target bacteria, fungi, and yeasts, respectively. CN-MRS medium prepared mixing Nutritive Broth from PanReac AppliChem, Spain and MRS (using half of the quantity recommended by the manufacturer for each single medium), was used for the in vitro antagonism assays.

All culture media were solidified with $2 \%$ agar, when necessary.

\subsection{Antimicrobial Assays}

\subsubsection{In Vitro Screening of LAB for Antimicrobial Activity}

For the in vitro tests, LAB and target bacteria and yeasts were grown in the appropriate medium until the exponential phase was reached. Fungi were grown in plates with the appropriate medium until spores or conidia were observed.

Antagonism assays between LAB and the target bacteria were done in CN-MRS, after verifying the growth of both types of bacteria in this medium. One hundred microliters of a cell suspension of the target bacteria $\left(10^{6}\right.$ cells $/ \mathrm{mL}$, according to MacFarland standards) were spread on a Petri dish (90 $\mathrm{mm}$ ) containing the appropriate medium. Then, a $5 \mu \mathrm{L}$ drop of a cell suspension of LAB strains ( $10^{6} \mathrm{cells} / \mathrm{mL}$ according to MacFarland standards) were spotted onto the plate. Plates were incubated for $48 \mathrm{~h}$ at $30^{\circ} \mathrm{C}$ for Bacillus species and $37^{\circ} \mathrm{C}$ for the rest of the strains.

Antagonism assays between $\mathrm{LAB}$ and the target yeasts were done in YEPD, after verifying the growth of both types of microorganisms in this medium. One hundred microliters of a cell suspension of the target yeasts $\left(10^{6} \mathrm{cells} / \mathrm{mL}\right.$, counted in a haemocytometer) were spread on a petri dish $(90 \mathrm{~mm})$ containing the appropriate medium. Then, a $5 \mu \mathrm{L}$ drop of a cell suspension of LAB strains $\left(10^{6} \mathrm{cells} / \mathrm{mL}\right.$ according to MacFarland standards) were spotted onto the plate. Plates were incubated for $72 \mathrm{~h}$ at $28^{\circ} \mathrm{C}$.

Each assay was done once with three replicates. In all cases, the inhibition degree was determined by measuring the radius of the inhibition halo around the LAB spot.

Antagonism assays between LAB and the target fungi were done in MRS, after verifying the growth of both types of microorganisms in this medium. A $5 \mu \mathrm{L}$ drop of a spores or conidia suspension in $0.85 \% \mathrm{NaCl}\left(10^{4}\right.$ spores $/ \mathrm{mL}$, counted in a haemocytometer) was spotted at one $\mathrm{cm}$ from the edge of a Petri dish $(60 \mathrm{~mm})$ containing the appropriate medium. Then, a $5 \mu \mathrm{L}$ drop of a cell suspension of LAB strains ( $10^{6}$ cells $/ \mathrm{mL}$ according to MacFarland standards) was spotted at the opposite end of the same plate. Two variants were performed for this test: In one of them, bacteria and fungi were inoculated simultaneously, while in the other, the LAB strain was allowed to grow for $48 \mathrm{~h}$ before inoculating the mold strain. A plate inoculated only with the fungus was included as control. Plates were incubated at $28^{\circ} \mathrm{C}$ for $96 \mathrm{~h}$.

Each assay was performed once with three replicates. The inhibition degree was determined by the formula R1-R2/R1 $\times 100$, where R1 is the radius of the fungus colony in the control plate and R2 the radius of the fungus colony in the antagonism assay plate.

\subsubsection{In Vivo Antifungal Activity}

Solanum lycopersicum, variety Marmande Cuarenteno, was used for determining the protective effect of LAB over adult tomato plants following the protocol described by Omar et al. [23] with some modifications. 
The seeds were kept soaking for $3 \mathrm{~h}$ and then moved to a germinator where they were stored for 5 days in darkness at $15^{\circ} \mathrm{C}$. Subsequently, they were moved into a commercial natural substrate (Nutrients: $\mathrm{N}=200-450 \mathrm{mg} / \mathrm{L}, \mathrm{P}_{2} \mathrm{O}_{5}=200-500 \mathrm{mg} / \mathrm{L}, \mathrm{K}_{2} \mathrm{O}=1500-2200 \mathrm{mg} / \mathrm{L}, \mathrm{pH}=5.0$ to 6.5) where they grew for 10 days before being transplanted into individual pots of $4 \times 4 \mathrm{~cm}$, containing the same substrate.

After 4 days of post-transplant adaptation, $1 \mathrm{~mL}$ of a conidial suspension $\left(10^{8}\right.$ conidia/mL $)$ of F. oxysporum $\mathrm{f}$. sp. lycopersici CECT 2715 was added in the base of the plant. In parallel, $1 \mathrm{~mL}$ of a cell suspension prepared in sterile natural water $\left(10^{6} \mathrm{cells} / \mathrm{mL}\right)$ of the corresponding LAB strain (L. paracasei LPAUV12 or L. plantarum LPLUV10), was also inoculated in the base of the plant.

All plants were watered every 4 days with $13 \mathrm{~mL}$ of sterile natural water per plant, applied in the base of the pot, and with $1 \mathrm{~mL}$ of a bacterial suspension $\left(10^{6} \mathrm{cells} / \mathrm{mL}\right)$, prepared in sterile natural water, also applied in the base of the plant. Two controls consisting of tomato plants not inoculated or inoculated only with F. oxysporum were also included in the experiment. The experiment was done once including 13 replicates per treatment. After 30 days of growth, tomato plants were harvested and the dry weight determined.

\subsection{Plant Growth Promoting Assay}

A possible growth-promoting effect of the selected LAB strains on the development of tomato plants was also studied.

The seeds were kept soaking for $3 \mathrm{~h}$ and then moved to a germinator where they were stored for 5 days in darkness at $15^{\circ} \mathrm{C}$. Subsequently, they were moved into a commercial natural substrate (Nutrients: $\mathrm{N}=200-450 \mathrm{mg} / \mathrm{L}, \mathrm{P}_{2} \mathrm{O}_{5}=200-500 \mathrm{mg} / \mathrm{L}, \mathrm{K}_{2} \mathrm{O}=1500-2200 \mathrm{mg} / \mathrm{L}, \mathrm{pH}=5.0$ to 6.5) where they grew for 10 days before being transplanted into individual pots of $4 \times 4 \mathrm{~cm}$, containing the same substrate.

After 4 days of post-transplant adaptation, $1 \mathrm{~mL}$ of a cell suspension prepared in sterile natural water $\left(10^{6}\right.$ cells $\left./ \mathrm{mL}\right)$ of the corresponding LAB strain (L. paracasei LPAUV12 or L. plantarum LPLUV10), was inoculated in the base of the plant.

All plants were watered every 4 days with $13 \mathrm{~mL}$ of sterile natural water per plant, applied in the base of the pot, and with $1 \mathrm{~mL}$ of a bacterial suspension $\left(10^{6}\right.$ cells $\left./ \mathrm{mL}\right)$, prepared in sterile natural water, also applied in the base of the plant. A control, consisting of tomato plants with no addition of bacteria, was also included. Each treatment was performed once including 13 replicates. After 30 days of growth, tomato plants were harvested and the dry weight determined.

\subsection{Statistical Analyses}

Statistical analyses were performed using the SPSS Statistics version 22 (IBM Corp.) program. In all cases, it was carried out a comparison of means by an analysis of variance (ANOVA), applying the Tukey (for in vitro antagonism assays) or Dunnett (for in vivo antifungal activity and plant growth promoting assay) tests, accepting a significance value of $95 \%(p \leq 0.05)$.

\section{Results and Discussion}

\subsection{Antimicrobial Activity Spectrum of $L A B$}

Twenty-two different strains of lactic acid bacteria of wine origin belonging to four different species were tested for their possible antimicrobial activity. As strains susceptible to inhibition, different species of bacteria and yeasts of environmental importance, present in food or able to behave as pathogens or food spoilage microorganisms were chosen. The antimicrobial activity of the lactic strains was evidenced by a microbial antagonism plate bioassay. The results are shown in Table 1 .

It was observed that none of the strains studied was able to inhibit the development of the tested yeasts, which agrees with the results obtained by Rouse et al. [1] with L. plantarum. This work also 
shows that the species L. hilgardii, L. paracasei and L. lactis do not have the capacity to inhibit the growth of yeasts.

It was also noted that none of the strains tested has the ability to inhibit the Gram-negative bacterium X. campestris, a pathogen of plants. In this sense, Anas et al. [24] described a greater inhibitory effect against Gram-positive bacteria than against Gram-negative by strains of the genus Lactobacillus.

With respect to the Gram-positive bacteria, it was observed that all of them were inhibited by at least one of the species of lactic bacteria analyzed, appreciating, in addition, a high intraspecific variability in both the efficacy and the spectrum of activity. The specificity of the species L. hilgardii, which inhibits only strains of the genus Bacillus, is remarkable; both B. cereus, a traditional food-spoilage pathogen, and B. thuringiensis, recently considered by the EFSA [25] to have the same potential risk to public health. As far as we know, this is the first time that the inhibitory capacity of L. hilgardii against the genus Bacillus has been described. In contrast, strains of L. plantarum were more effective against the genus Staphylococcus, both for the pathogenic species S. aureus and for S. epidermidis which, although commensal, can behave as opportunistic pathogen [26]. The greatest effectiveness, considering both the degree of inhibition and the number of inhibited species, was shown by strains of L. lactis and L. paracasei. L. paracasei showed inhibitory effects against the four Gram-positive species tested, although the greatest effect was detected against the species of the genus Staphylococcus. Although Anas et al. [24] had previously described the ability of this lactic species to inhibit S. aureus, its antagonistic effect against $B$. cereus, B. thuringiensis and S. epidermidis has not been described.

Different studies have shown the antagonistic effect of LABs of different origins against pathogenic microorganisms [24,27,28], also demonstrating variability in their effectiveness [29]. This variability in the inhibitory power and, in addition, in the spectrum of activity are also found in lactic strains of vinous origin, confirming the need for characterization at this level, prior to a possible use of these microorganisms as bio protective agents.

The antibacterial activity shown by the wine LAB characterized in this study turns them into microorganisms with potential interest as bio preservative agents. This property can be, first, of great interest during winemaking itself, as might allow a reduction in the amount of chemical preservatives added to them, particularly $\mathrm{SO}_{2}$, whose adverse health effects have been reliable and heavily verified [30]. This interest is increased due to the capacity, shown in this work, of some strains to inhibit the development of the species S. epidermidis, responsible for the increase in biogenic amines of some wines [31] which also emphasizes the importance and the interest of the Lactobacillus genus to prepare malolactic starters. Furthermore, the characterization of the antibacterial activity of different species of lactic bacteria (in addition to the most studied, L. plantarum), allowed to select different strains of broad spectrum, as well as others more specific, identifying new effective species against undesirable pathogenic and/or food spoilage microorganisms.

The possible inhibitory effect of malolactic bacteria against filamentous fungi was also tested. For this, the lactic strains belonging to the species L. paracasei and L. plantarum were chosen because they had a broader spectrum of action and a greater degree of inhibition against bacteria. The fungi susceptible to inhibition were A. niger and F. oxysporum, two phytopathogenic fungi that can also appear as contaminants of seeds and as spoilage microorganisms in post-harvest fruits and foods. The antimicrobial activity of lactic acid bacteria against fungi was estimated by a plate bioassay with two variants: In one, the bacteria and fungus were simultaneously inoculated and, in the other, the bacterium was previously incubated for $48 \mathrm{~h}$ before the inoculation of the fungus.

First, it was observed that none of the strains under study was able to inhibit $A$. niger. However, all the strains were able to inhibit in vitro the growth of F. oxysporum. For four of the strains (LPAUV3, 5,7 and LPLUV10) the inhibitory capacity is significantly higher when the bacteria are previously incubated before facing the fungus, although in all of them the same tendency is observed (Figure 1A). Comparing the degree of inhibition of the fungus shown by the different bacterial strains both without (Figure 1B) and with (Figure 1C) previous incubation, a certain variability in the inhibitory power is observed, manifested by the significant differences found between them. The degree of inhibition 
ranges from 55\% (strain LPLUV10) when the bacteria and fungus are inoculated simultaneously and $76 \%$ (strain LPAUV7) when the bacteria is previously cultured for $48 \mathrm{~h}$. Previous studies have demonstrated the effectiveness of strains of L. plantarum from other sources to inhibit the development of phytopathogenic fungi, including F. oxysporum $[1,7,14,32]$. When comparing the data relative to the degree of inhibition of F. oxysporum obtained in this work with some of the best previous results that describe inhibitions of up to 50\% [32], a high and very competitive efficacy of the malolactic strains is observed. On the other hand, with respect to the species L. paracasei, with the exception of the work carried out by Liang et al. [33], which studies a strain of human origin, there were no more data regarding the antagonism of this species against $F$. oxysporum. The antifungal activity shown by lactic acid bacteria has been attributed to its ability to produce and release metabolites such as reuterin, organic acids or phenolic compounds [7] as well as antifungal substances of protein nature [4].
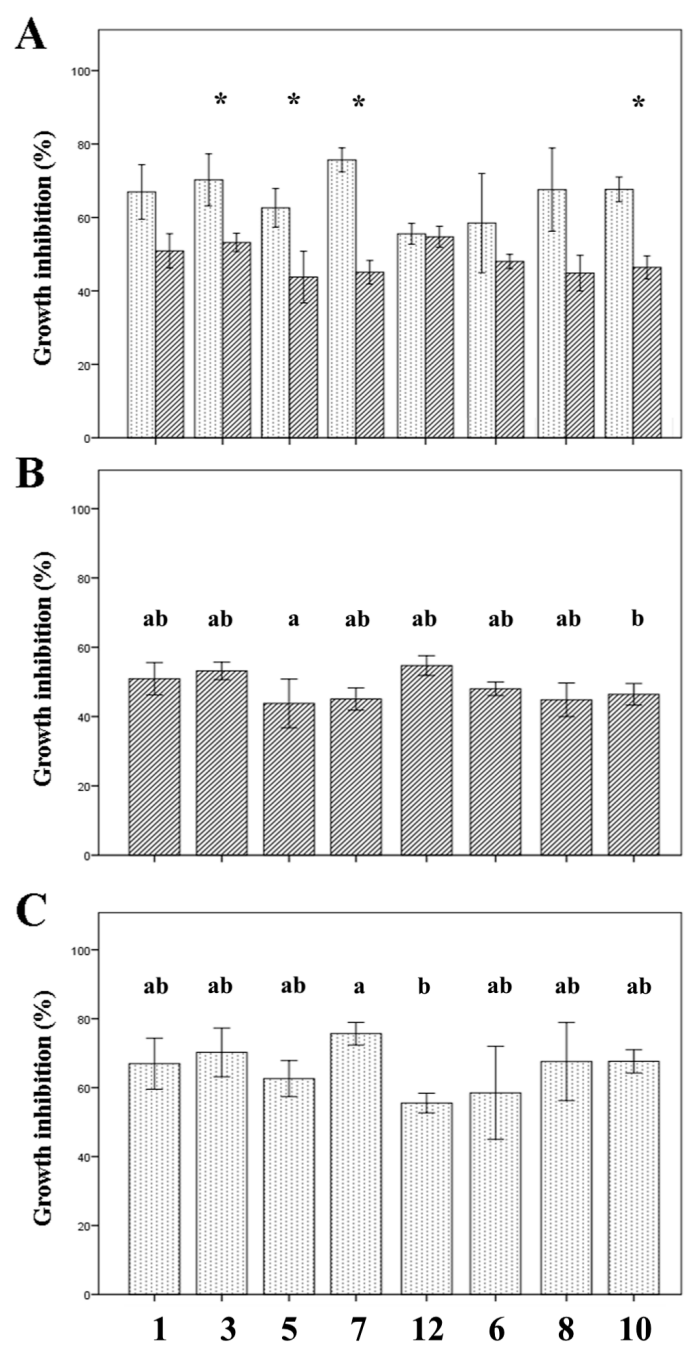

Figure 1. F. oxysporum growth inhibition by wine lactic acid bacteria (LAB). (A): Comparison in the efficacy of the inhibition by the LAB strains when bacteria and fungus were inoculated simultaneously (dark bars) or when bacteria were allowed to grow for $48 \mathrm{~h}$ before inoculating the fungus (white bars). Values are mean \pm SD. $\left.{ }^{*}\right)$ : Significant differences $(p \leq 0.05)$. (B): Comparison of the antifungal effect of the different $\mathrm{LAB}$ strains when bacteria and fungus were inoculated simultaneously. (C): Comparison of the antifungal effect of the different LAB strains when bacteria were cultured for $48 \mathrm{~h}$ before fungus inoculation. Values are mean \pm SD. Different letters indicate significant differences $(p \leq 0.05)$. 1: LPAUV1, 3: LPAUV3, 5: LPAUV5, 7: LPAUV7, 12: LPAUV12, 6: LPLUV6, 8: LPLUV8, 10: LPLUV10. 
The antifungal activity of these strains turns them into microorganisms of potential utility for the biocontrol of F. oxysporum in crops and post-harvest products. In addition, this fungicidal activity in combination with the antibacterial activity demonstrated in the previous section, increases its potential interest as BCAs. On the other hand, their demonstrated inability to inhibit the growth of A. niger and the yeasts tested in this study confers them a certain degree of specificity when compared with other strains of a broader spectrum $[1,4,34]$, property that would depend on the strain, justifying screening and selection at this level. This characteristic can be considered very desirable in view of its use as bio preservatives in products in whose production and/or composition the presence of other viable fungi or yeasts is required.

\subsection{Plant-Probiotic Potential of LAB: Efficacy as BCAs and PGPS}

Based on the high antifungal activity against $F$. oxysporum in the in vitro tests, the L. plantarum LPLUV10 and L. paracasei LPAUV12 strains were chosen to evaluate their potential to carry out the biocontrol of the fungus in Lycopersicon esculentum plants. Both the effect of the fungus on the plant and the bio protection of the same by the bacteria were estimated determining their influence on the dry weight of the whole plant.

Figure 2 shows, qualitatively, the effect of the fungus and the bio protective capacity of the lactic acid bacteria analyzed on the plant. This effect manifests itself in an apparent reduction in the length of the stem and roots in the case of plants treated with the fungus compared to the plants treated with the fungus and lactic acid bacteria, in particular with the LPLUV10 strain.

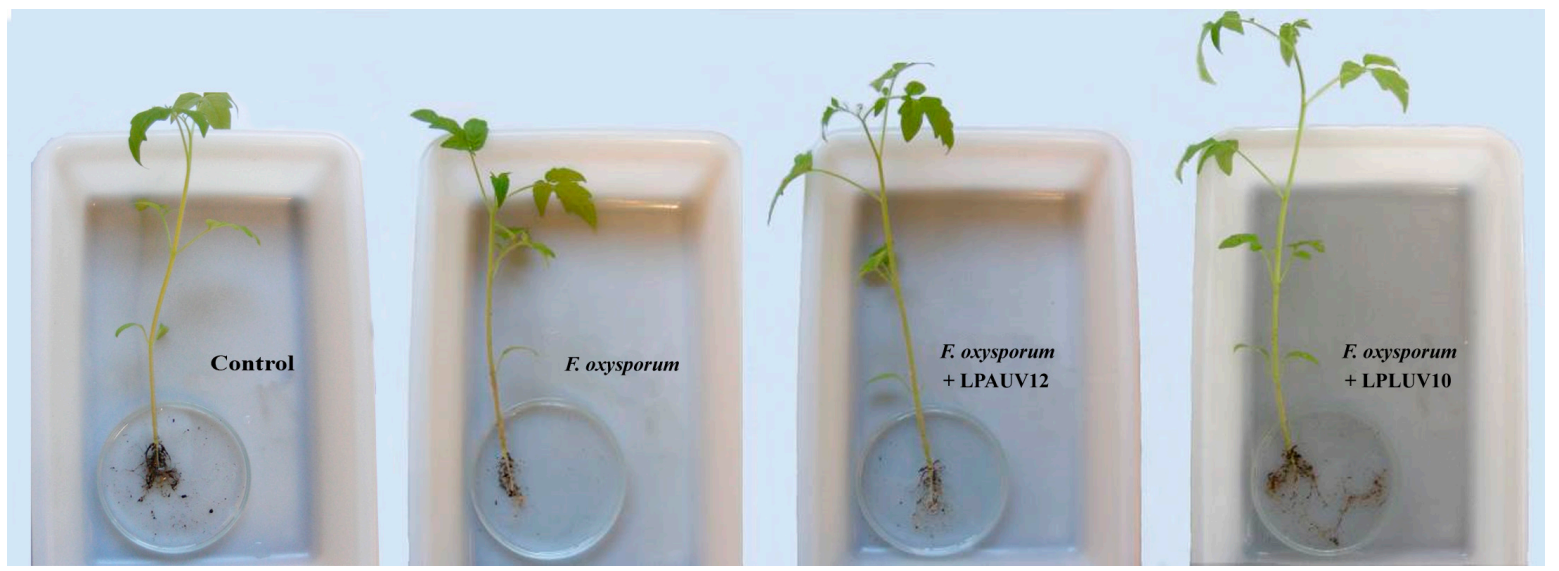

Figure 2. Qualitative effect of F. oxysporum on untreated L. esculentum plants and the bioprotective capacity of the studied lactic acid bacteria.

Quantitatively, in the first place, the effect of the fungus on the plant was observed, showing a significant reduction (ca. 20\%) of its dry weight after 30 days of culture (Figure 3A). Secondly, the protective effect of the lactic bacteria analyzed on the harmful effect induced in the plant by F. oxysporum was demonstrated. Figure 3B shows a significant reduction in the damaging effect of the fungus, used as a control, in plants treated with wine malolactic bacteria, specifically with the L. plantarum strain LPLUV10 (ca. 24\%). 
A

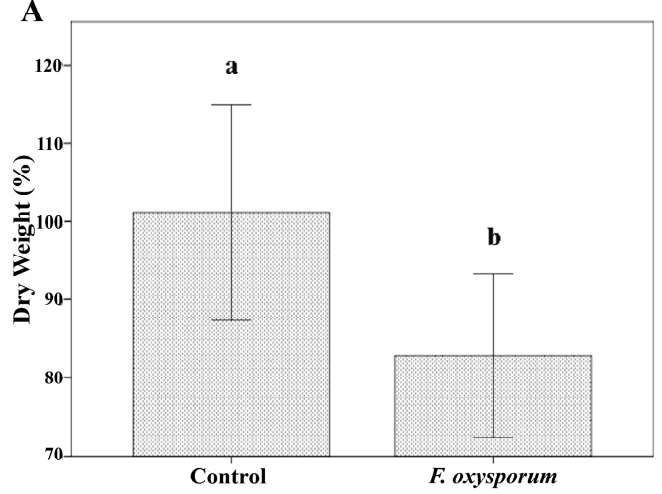

C

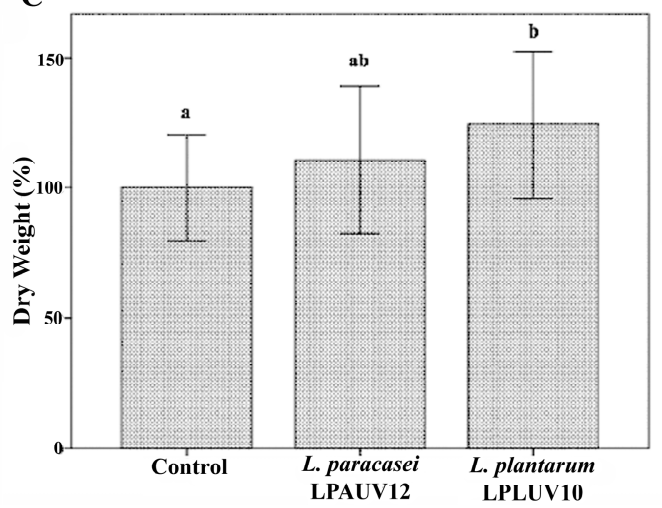

B

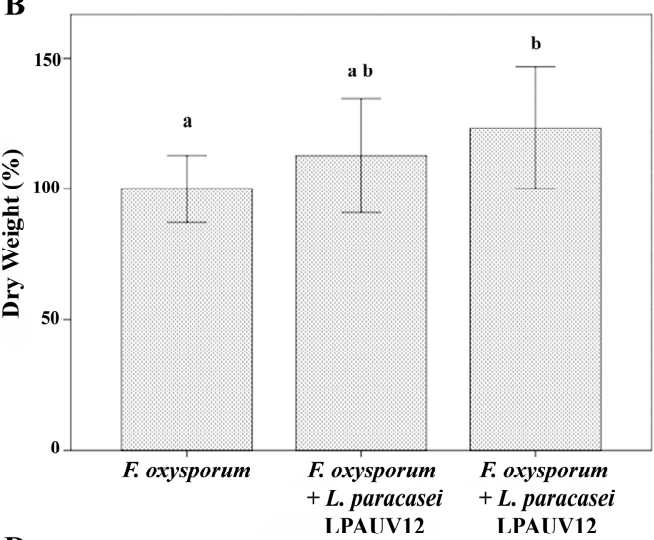

D

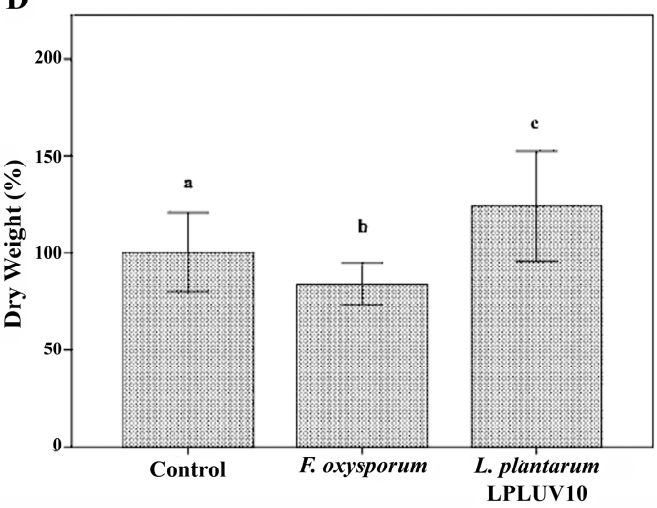

Figure 3. Ability of selected malolactic strains to act as biocontrol and biofertilizer agents. (A): Effect of F. oxysporum on L. esculentum plants. (B): Effect of the treatment with selected LAB strains on the infection of L. esculentum plants by F. oxysporum. (C): Effect of the treatment with selected LAB strains on the growth of L. esculentum plants. (D): Effect of the treatment with strain LPLUV10 on the growth of L. esculentum plants in comparison with plants infected with F. oxysporum. Values are mean \pm SD. Different letters indicate significant differences $(p \leq 0.05)$.

Due to the important economic repercussions that F. oxysporum causes in the agri-food industry, since the year 2000 there is a growing interest in the biological control of this fungus [35]. In most of the studies, there are genera or bacterial and/or fungal species associated with the roots that have shown a remarkable inhibitory effect on the development of the fungus after its application in tomato plants [23,36,37]. However, as far as we know, only Hamed et al. [38], had demonstrated the capacity of lactic acid bacteria (isolated from dairy products) for the bio protection of plants against F. oxysporum, in an experiment that requires the previous protection of the seed with the bacteria. In the present work, the capacity of the strain L. plantarum LPLUV10 of wine origin for the biocontrol of F. oxysporum has been demonstrated by adding it to the irrigation water. On the other hand, previous studies have shown that, in the case of some bacteria of the rhizosphere, their effectiveness as biocontrol agents depends on whether they are used to protect the crop from which they were isolated, showing little or no efficacy in the protection of other cultivations [39], which would imply the need to obtain specific biocontrol agents. In the present study it is shown that the malolactic strain LPLUV10 is capable of reducing the pernicious effect of F. oxysporum on tomato plants coming from a different habitat, thus demonstrating potentially, a more broad-spectrum efficacy.

In conventional agriculture, in addition to synthetic pesticides for the control of agricultural pests, chemical fertilizers are extensively used to strengthen, stimulate and accelerate the growth of plants. The use of chemical fertilizers has important detrimental effects for living beings and leads to important environmental alterations [40]. The most innovative approaches in agricultural production demand new biologically based fertilizers, alternative to agrochemicals, based on Plant Growth-Promoting 
Bacteria, PGPB, [41]. Accordingly, in this work we also checked whether the L. plantarum LPLUVI10 and L. paracasei LPAUVI12 strains could promote the growth of tomato plants. The results showed an increase in the dry weight of the plants inoculated with the studied strains of lactic bacteria. This increase was significant (ca. 24\%) in those that were irrigated with L. plantarum LPLUV10 when compared with the control not treated with bacteria (Figure 3C). This increase represents about $41 \%$ with respect to the plants infected with F. oxysporum (Figure 3D). Taking all the results together would indicate that the bio protection exerted by the bacteria on the infected plants could be due to a combination of their antagonistic action on the pathogen and its phytostimulatory effect on the plant. The ability to stimulate plant growth has been studied in various bacteria, mostly in those that form the rhizosphere microbiota $[39,42,43]$. Microorganisms that enhance the growth and suppress diseases of the host plants are known as plant probiotics [44]. The results of this study show that lactic acid bacteria, particularly those isolated from wine, can also act as plant growth stimulants as well as BCAs.

In conclusion, the present work demonstrates that strains of wine lactic acid bacteria from different species show a powerful and competitive antibacterial and antifungal activity, characterizing new effective species against undesirable pathogenic and/or spoilage microorganisms. The different strains differ both in their effectiveness and their spectrum of activity, which makes screening at this level necessary to meet specific needs. In addition, the L. plantarum LPLUV10 strain showed the ability to significantly inhibit the harmful effect of $F$. oxysporum in tomato plants, as well as to significantly stimulate its growth, behaving as a potential probiotic for the plant. Given its proven antimicrobial capacity, lactic acid bacteria of wine can have interest as bio preservative, biocontrol, and PGPs agents. These bacteria could be used individually or in combination with other agents. With regard to its use in real applications, it would be of great interest to carried out more in-depth studies on their mechanisms of action and behaviour in the field.

Author Contributions: J.L.-S. conceived the experimental design and performed the in vitro and in vivo antimicrobial experiments. Also he participated in the discussion of the results and in the writing of the manuscript. B.G.-F. carried out part of the in vivo antifungal experiments and participated in the interpretation and discussion of the results. A.F.d.S. carried out part of in vitro antimicrobial bioassays and participated in the interpretation and discussion of the results. C.S. designed the research, supervised the work, participated in the revision and discussion of the results and drafted the manuscript. All authors have read and agreed to the published version of the manuscript.

Acknowledgments: This work was supported by the University of Vigo and the Sustainable Use Network of Environmental and Agrifood Resource-REDUSO-(Xunta de Galicia, CN2012/108). J.L.-S. was a recipient of a predoctoral fellowship from the University of Vigo, Spain.

Conflicts of Interest: The authors declare no conflict of interest.

\section{References}

1. Rouse, S.; Harnett, D.; Vaughan, A.; Van Sinderen, D. Lactic acid bacteria with potential to eliminate fungal spoilage in foods. J. Appl. Microbiol. 2008, 104, 915-923. [CrossRef] [PubMed]

2. Food and Agriculture Organization (FAO). Available online: www.FAO.org (accessed on 9 November 2019).

3. Gram, L.; Ravn, L.; Rasch, M.; Bruhn, J.B.; Christensen, A.B.; Givskov, M. Food spoilage-interactions between food spoilage bacteria. Int. J. Food Microbiol. 2002, 78, 79-97. [CrossRef]

4. Gerez, C.L.; Torres, M.J.; Font de Valdez, G.; Rollán, G. Control of spoilage fungi by lactic acid bacteria. Biol. Control 2013, 64, 231-237. [CrossRef]

5. Remenant, B.; Jaffrés, E.; Dousset, X.; Pilet, M.F.; Zagorec, M. Bacterial spoilers of food: Behavior, fitness and functional properties. Food Microbiol. 2015, 45, 45-53. [CrossRef] [PubMed]

6. Pepe, O.; Blaiotta, G.; Moschetti, G.; Greco, T.; Villani, F. Rope-producing strains of Bacillus spp. from wheat bread and strategy for their control by lactic acid bacteria. Appl. Environ. Microbiol. 2003, 69, 2321-2329. [CrossRef]

7. Dalié, D.K.D.; Deschamps, A.M.; Richard-Forget, F. Lactic acid bacteria-Potential for control of mould growth and mycotoxins: A review. Food Control 2010, 21, 370-380. [CrossRef]

8. Syed AbRahman, S.F.; Singh, E.; Pieterse, C.M.J.; Schenk, P.M. Emerging microbial biocontrol strategies for plant pathogens. Plant Sci. 2017, 267, 102-111. [CrossRef] 
9. Jess, S.; Kildea, S.; Moody, A.; Rennick, G.; Murchie, A.K.; Cooke, L.R. European Union policy on pesticides: Implications for agriculture in Ireland. Pest Manag. Sci. 2014, 70, 1646-1654. [CrossRef]

10. Zhang, P.; Zhu, Y.; Ma, D.; Xu, W.; Zhou, J.; Yan, H.; Yang, L.; Yin, J. Screening, identification, and optimization of fermentation conditions of an antagonistic endophyte to wheat head blight. Agronomy 2019, 9, 476. [CrossRef]

11. Di Francesco, A.; Mari, M. Use of biocontrol agents in combination with physical and chemical treatments: Efficacy assessment. Stewart Postharvest Rev. 2014, 10, 2.

12. Hasan, S.; Gupta, G.; Anand, S.; Chaturvedi, A.; Kaur, H. Biopotential of microbial antagonists against soilborne fungal plant pathogens. Int. J. Agric. Food Sci. Technol. 2013, 4, 37-39.

13. Sathe, S.J.; Nawani, N.N.; Dhakephalkar, P.K.; Kapadnis, B.P. Antifungal lactic acid bacteria with potential to prolong shelf-life of fresh vegetables. J. Appl. Microbiol. 2007, 103, 2622-2628. [CrossRef] [PubMed]

14. Schnürer, J.; Magnusson, J. Antifungal lactic acid bacteria as biopreservatives. Trends Food Sci. Technol. 2005, 16, 70-78. [CrossRef]

15. Spadaro, D.; Gullino, M.L. State of the art and future prospects of the biological control of postharvest fruit diseases. Int. J. Food Microbiol. 2004, 91, 185-194. [CrossRef]

16. Koul, O. Microbial biopesticides: Oportunities and challenges. CAB Rev. 2011, 6, 1-26.

17. Mari, M.; Di Francesco, A.; Bertolini, P. Control of fruit postharvest diseases: Old issues and Innovative approaches. Stewart Postharvest Rev. 2014, 10, 1.

18. Le Mire, G.; Nguyen, M.L.; Fassotte, B.; du Jardin, P.; Verheggen, F.; Delaplace, P.; Jijakli, M.H. Review: Implementing plant biostimulants and biocontrol strategies in the agroecological management of cultivated ecosystems. Biotechnol. Agron. Soc. Environ. 2016, 20, 299-313.

19. Latour, X.; Barbey, C.; Chane, A.; Groboillot, A.; Burini, J.-F. Rhodococcus erythropolis and its $\gamma$-lactone catabolic pathway: An unusual biocontrol system that disrupts pathogen quorum sensing communication. Agronomy 2013, 3, 816-838. [CrossRef]

20. Ahmad, F.; Ahmad, I.; Khan, M.S. Screening of free-living rhizospheric bacteria for their multiple plant growth promoting activities. Microbiol. Res. 2008, 163, 173-181. [CrossRef]

21. Carmona-Hernandez, S.; Reyes-Pérez, J.J.; Chiquito-Contreras, R.G.; Rincon-Enriquez, G.; Cerdan-Cabrera, C.R.; Hernandez-Montiel, L.G. Biocontrol of postharvest fruit fungal diseases by bacterial antagonists: A review. Agronomy 2019, 9, 121. [CrossRef]

22. Lamont, J.R.; Wilkins, O.; Bywater-Ekegärd, M.; Smith, D.L. From yogurt to yield: Potential applications of lactic acid bacteria in plant production. Soil Biol. Biochem. 2017, 111,1-9. [CrossRef]

23. Omar, I.; O'Neill, T.M.; Rossall, S. Biological control of Fusarium crown and root rot of tomato with antagonistic bacteria and integrated control when combined with the fungicide carbendazim. Plant Pathol. 2006, 55, 92-99. [CrossRef]

24. Anas, M.; Eddine, H.J.; Mebrouk, K. Antimicrobial activity of Lactobacillus species isolated from Algerian raw goat's milk against Staphylococcus aureus. World J. Dairy Food Sci. 2008, 3, 39-49.

25. EFSA BIOHAZ Panel. Risks for public health related to the presence of Bacillus cereus and other Bacillus spp. including Bacillus thuringiensis in foodstufs. EFSA J. 2016, 14, 4524.

26. Otto, M. Staphylococcus epidermidis-The "accidental" pathogen. Nat. Rev. Microbiol. 2009, 7, 555-567. [CrossRef]

27. Amin, M.; Jorfi, M.; Khosravi, A.D.; Samarbafzadeh, A.R.; Farajzadeh Sheikh, A. Isolation and Identifiction of Lactobacillus casei and Lactobacillus plantarum from plants by PCR and detection of their antibacterial activity. J. Biol. Sci. 2009, 9, 810-814.

28. Askari, G.A.; Kahouadji, A.; Khedid, K.; Charof, R.; Mennane, Z. Screening of lactic acid bacteria isolated from dried fruits and study of their antibacterial activity. Middle-East J. Sci. Res. 2012, 11, $209-215$.

29. Kivanç, M.; Yilmaz, M.; Çakir, E. Isolation and identification of lactic acid bacteria from boza, and their microbial activity against several reporter strains. Turk. J. Biol. 2011, 35, 313-324.

30. Lester, M.R. Sulfite sensitive: Significance in human health. J. Am. Coll. Nutr. 1995, 14, 229-232. [CrossRef]

31. Benavent-Gil, Y.; Berbegal, C.; Lucio, O.; Pardo, L.; Ferrer, S. A new fear in wine: Isolation of Staphylococcus epidermidis histamine producer. Food Control 2016, 62, 142-149. [CrossRef]

32. Laitila, A.; Alakomi, H.L.; Raaska, L.; Mattila-Sandholm, T.; Haikara, A. Antifungal activities of two Lactobacillus plantarum strains against Fusarium moulds in vitro and in malting of barley. J. Appl. Microbiol. 2002, 93, 566-576. [CrossRef] [PubMed] 
33. Liang, T.-W.; Wu, Y.-Y.; Wang, C.-Y.; Yen, Y.-H.; Liu, C.-P.; Wang, S.-L. Conversion of squid pen by a novel strain Lactobacillus paracasei subs. paracasei TKU010, and its application in antimicrobial and antioxidants activity. J. Gen. Appl. Microbiol. 2010, 56, 481-489. [PubMed]

34. Hasan, Y.L.; Bullerman, L.B. Antifungal activity of Lactobacillus paracasei ssp. tolerans isolated from a sourdough bread culture. Int. J. Food Microbiol. 2008, 121, 112-115.

35. Raza, W.; Ling, N.; Zhang, R.; Huang, Q.; Xu, Y.; Shen, Q. Success evaluation of the biological control of Fusarium wilts of cucumber, banana, and tomato since 2000 and future research strategies. Crit. Rev. Biotechnol. 2016, 8551, 1-11. [CrossRef] [PubMed]

36. Larkin, R.P.; Fravel, D.R. Efficacy of various fungal and bacterial biocontrol organisms for control of Fusarium wilt of tomato. Plant Dis. 1998, 82, 1022-1028. [CrossRef] [PubMed]

37. Mao, W.; Lewis, J.A.; Lumsden, R.D.; Hebbar, K.P. Biocontrol of selected soilborne diseases of tomato and pepper plants. Crop Prot. 1998, 17, 535-542. [CrossRef]

38. Hamed, H.; Moustafa, Y.; Abdel-Aziz, S. In vivo efficazy of lactic acid bacteria in biological control against Fusarium oxysporum for protection of tomato plant. Life Sci. J. 2011, 8, 462-468.

39. Vaikuntapu, P.R.; Dutta, S.; Samudrala, R.B.; Rao, V.R.V.N.; Kalam, S.; Podile, A.R. Preferential promotion of Lycopersicon esculentum (Tomato) growth by plant growth promoting bacteria associated with tomato. Indian J. Microbiol. 2014, 54, 403-412. [CrossRef]

40. Savci, S. An Agricultural Pollutant: Chemical fertilizer. IJESD 2012, 3, 11-14. [CrossRef]

41. Bhardwaj, D.; Ansari, M.W.; Sahoo, R.K.; Tuteja, N. Biofertilizers function as key player in sustainable agriculture by improving soil fertility, plant tolerance and crop productivity. Microb. Cell Factories 2014, 13, 66. [CrossRef]

42. Giassi, V.; Kiritani, C.; Kupper, K.C. Bacteria as growth-promoting agents for citrus rootstocks. Microbiol. Res. 2016, 190, 46-54. [CrossRef] [PubMed]

43. Urrea, R.; Cabezas, L.; Sierra, R.; Cárdenas, M.; Restrepo, S.; Jiménez, P. Selection of antagonistic bacteria isolated from the Physalis peruviana rhizosphere against Fusarium oxysporum. J. Appl. Microbiol. 2011, 111, 707-716. [CrossRef] [PubMed]

44. Kim, Y.C.; Anderson, A.J. Rhizosphere pseudomonads as probiotics improving plant health. Mol. Plant Pathol. 2018, 19, 2349-2359. [CrossRef] [PubMed]

(C) 2019 by the authors. Licensee MDPI, Basel, Switzerland. This article is an open access article distributed under the terms and conditions of the Creative Commons Attribution (CC BY) license (http://creativecommons.org/licenses/by/4.0/). 